\title{
Spawning dynamics in the Hawaiian reef-building coral Montipora capitata
}

\author{
Jacqueline L. Padilla-Gamiño ${ }^{1,2,3, *}$, Ruth D. Gates ${ }^{2}$ \\ ${ }^{1}$ Department of Oceanography, University of Hawai'i, 1000 Pope Road, Honolulu, Hawaii 96822, USA \\ ${ }^{2}$ Hawai'i Institute of Marine Biology, PO Box 1346, Kaneohe, Hawaii 96744, USA \\ ${ }^{3}$ Present address: Marine Science Institute, University of California Santa Barbara, Santa Barbara, California 93106-6150, USA
}

\begin{abstract}
The release of gametes into the water column by broadcast-spawning marine invertebrates represents the culmination of several physiological events in the parents and the first step in the supply of new recruits to marine ecosystem. The input of new propagules to coral reefs relies on spawning events that display remarkable synchronicity during limited periods each year. Although the timing of spawning is known for most species, other aspects of coral reproduction (polyp fecundity or spawning synchronicity) are less understood. This largely reflects the sporadic nature of reproductive activities and logistical problems of studying the ephemeral coral spawning events in situ on the reef at night. Here, we address this gap by exploring the spatial and temporal spawning dynamics of Montipora capitata, a broadcast-spawning, reef-building coral from the central Pacific Ocean, by using the systematic sampling of gametes in the field. Our results indicate that spawning in this species varies among years, months and lunar days, and that the proportion of colonies spawning and synchrony of spawning do not reflect coral colony morphology, colony size or the differences in environments between sites within a year. Major differences in reproductive outputs (spawned material) were observed between the 2 yr studied, which most probably reflects variability in temperature between years or shifts in the timing of spawning (phenology). This study highlights the complexity of spawning dynamics in corals and suggests that a more comprehensive understanding of interplay between reproduction and environment is fundamentally important to accurately predict the effects of climate change in these important ecosystems.
\end{abstract}

KEY WORDS: Colonial marine invertebrate $\cdot$ Phenotypic plasticity $\cdot$ Spawning synchronicity Phenology $\cdot$ Colony size $\cdot$ Lipids

\section{INTRODUCTION}

The release of gametes into the environment is ubiquitous among marine invertebrates and has been well studied in a number of phyla including echinoderms, annelids, mollusks, cnidarians and sponges (Babcock et al. 1992, Minchin 1992, Van Veghel 1993, Himmelman et al. 2008, Mercier \& Hamel 2010). Reef-building (scleractinian) corals provide an aston- ishing example of organisms that synchronously release gametes into the water column for external fertilization in multi-species spawning events (Babcock 1986, Richmond \& Hunter 1990, Baird et al. 2009, Harrison 2011). In areas such as the Great Barrier Reef (GBR), Australia, the spawning can include over 130 species and release enough gametes onto the reef to produce slicks up to $50000 \mathrm{~m}^{2}$ in area (Willis et al. 1985, Harrison \& Wallace 1990). 
Different cues from the environment interact to synchronize coral spawning and those most often linked to the control of spawning timing (at different timescales) are season, moon phase and sunset time (Harrison et al. 1984, Babcock et al. 1986, Hunter 1988, van Veghel 1993, Mendes \& Woodley 2002, van Woesik et al. 2006). Seasonally, spawning is influenced by sea surface temperature (SST) with many coral species spawning when the waters are warming or close to their annual maxima (Willis et al. 1985, Harrison \& Wallace 1990, Richmond \& Hunter 1990). In other locations, however, solar insolation and wind can be better seasonal predictors of spawning than SST (van Woesik et al. 2006, van Woesik 2010). At the scale of month, spawning timing is influenced by moonlight and tidal changes associated with lunar cycles (Willis et al. 1985). Corals possess blue-lightsensing photoreceptors (cryptochromes) that allow them to sense moonlight (Gorbunov \& Falkowski 2002, Levy et al. 2007) and manipulative experiments have shown that changes in lunar cycles influence the timing of gamete release (Hunter 1988). At the scale of day(s), the exact time (hour and minutes) of gamete release is linked to sunset time (Brady et al. 2009, Levitan et al. 2011).

Other reproductive traits such as egg size or colony fecundity are also influenced by environmental conditions (Fan \& Dai 1999). For example, changes in temperature are known to negatively affect coral physiology (e.g. bleaching), which has downstream effects on coral reproduction such as reduced polyp fecundity, egg size, fertilization success and overall reproductive output (McClanahan et al. 2009). The ways in which climate change will affect timing (phenology), spawning synchrony and reproductive output in corals is not well understood, but the impacts are likely to be profound given how environmentally entrained and sensitive reproductive activities in corals are. Hughes (2000) suggested that reproductive cues (e.g. temperature and light) that influence the timing of specific stages of gametogenesis and spawning could be decoupled owing to an earlier arrival of spring. This could have dramatic consequences for species that require high spawning synchronicity for reproductive success and that have restricted mating opportunities each year owing to their length of the oogenic cycles.

Although the spawning periods for many species of scleractinian corals are well documented (Harrison \& Wallace 1990, Richmond \& Hunter 1990, Baird et al. 2009), spatial and long-term temporal variation in coral reproductive capabilities are not well studied, a gap that reflects the sporadic nature of reproductive activities and logistical problems of studying ephemeral coral spawning events in situ on the reef at night. In past studies, coral colonies have been collected and observed in the lab; however, this effort has generally been restricted to small to medium-sized corals that are easily handled and maintained in aquaria. Traps have also been used to collect gametes in the field, but these have generally been small in size to facilitate deployment, an approach that has further contributed to the bias in data for small coral species and colonies. In addition, the same corals are rarely observed over multiple spawning periods and so temporal variation in spawning activities is not well characterized.

With the goal of better understanding factors that control spawning synchrony and reproductive output of important reef builders, this work explores in situ spatial (sites, colony, polyps) and temporal (years, months, days) spawning dynamics of Montipora capitata, a broadcast spawner from the central Pacific Ocean. This coral is one of the most abundant, important and phenotypically plastic reef-building species in the main Hawaiian Islands, USA, (Maragos 1972, Jokiel et al. 2004) and is a hermaphrodite broadcast spawner that releases egg-sperm bundles during the summer months (Hodgson 1985, Hunter 1988, Padilla-Gamino et al. 2011). To date it is unknown whether reproductive boundaries exist between colonies with different morphologies or whether different morphotypes have similar energy reserves available for reproduction. To address this gap, this study also explores the physiological state (lipids) and fertilization success of $M$. capitata colonies from different environments and with different morphological characteristics.

\section{METHODS}

\section{Location of study}

This study was implemented at 2 sites on the western side of Moku O Lo'e Island in Kane'ohe Bay (O'ahu, Hawai'i). The sites are referred to as Bridge to Nowhere (BTN; $\left.21^{\circ} 25.893^{\prime} \mathrm{N}, 157^{\circ} 47.376^{\prime} \mathrm{W}\right)$ and Gilligan's Lagoon (GL; $21^{\circ} 25.973^{\prime} \mathrm{N}, 157^{\circ} 47.392^{\prime} \mathrm{W}$ ) throughout. The Montipora capitata colonies studied at both sites were located at 1 to $2 \mathrm{~m}$ depth and coral colonies exhibited primarily branching morphologies at BTN and plating morphologies at GL (Fig. 1a-d, Fig. S1 in the Supplement at www.int-res.com/ articles/suppl/m449p145_supp.pdf). 

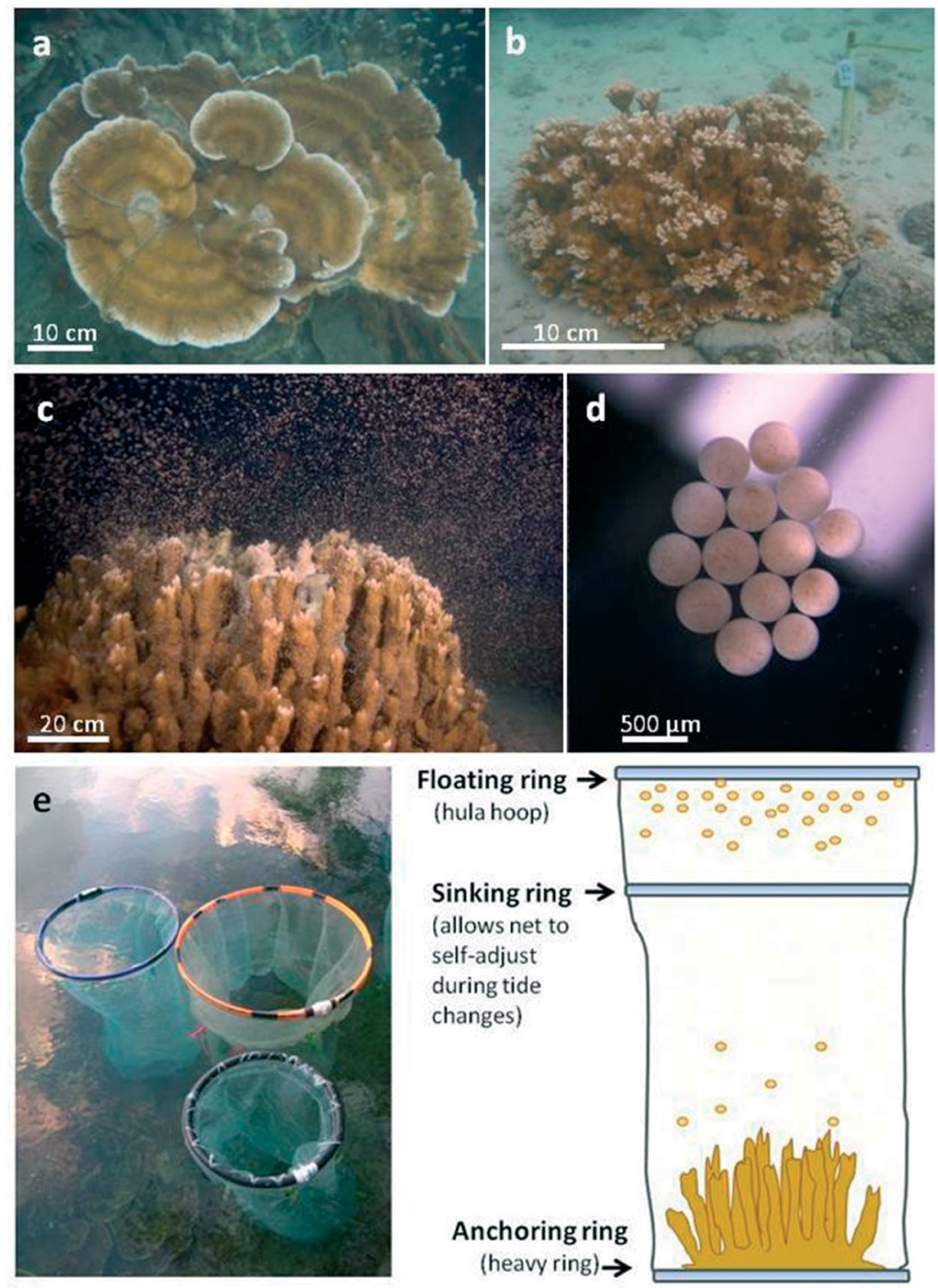

Fig. 1. Montipora capitata. Colonies representing (a) plating and (b) branching morphologies. (c) Larger branching colony spawning egg-sperm bundles. (d) Eggs: post release after egg-sperm bundle has been broken apart. (e) Photograph and schematic of nets used to collect buoyant egg-sperm bundles from individual colonies

\section{Comparisons of environmental characteristics across spawning years}

This study was conducted during spawning events in the summers of 2007 and 2008. To compare environmental characteristics between years, temperature, precipitation, wind and solar and UV radiation were examined. Environmental measurements were taken at the meteorological stations at the Hawai'i Institute of Marine Biology on Moku O Lo'e Island. Temperature was recorded with a temperature probe (model 107, Campbell Scientific), precipitation was recorded with a tipping bucket rain gauge (model TE525, Texas Electronics), wind was recorded with a wind monitor (model 05103, R. M. Young), sun-plus-sky radiation was measured with a silicon pyranometer (model L1200X-L, Campbell Scientific), which had a sensitivity of $0.2 \mathrm{~kW} \mathrm{~m}^{-2} \mathrm{mV}^{-1}$ and UV radiation was measured with a total UV radiometer (model TUVR, Eppley Laboratory), which had a sensitivity of $150 \mu \mathrm{V} / \mathrm{Wm}^{-2}$. All environmental variables were recorded hourly.

\section{Comparisons of environmental characteristics between sites}

Temperature and light regime were examined to compare environments at the BTN and GL sites. Temperature was measured at $10 \mathrm{~min}$ intervals for 1 yr in 2007 with StowAway Tidbits temperature loggers (Onset Computer) accurate to $\pm 0.2^{\circ} \mathrm{C}$. Light was measured during two $2 \mathrm{wk}$ periods in 2008 (22 September to 1 October and 25 November to 5 December) at both sites. Light measurements were taken at 10 min intervals with submersible Odyssey Photosynthetic Irradiance Recording Systems (Odyssey).

\section{Timing of spawning collections}

Egg-sperm bundles were collected for $3 \mathrm{~d}$ each month (June, July and August) starting on the night of the new moon during 2007 and 2008; these days were chosen based on previous observations of spawning events in the area (F. Cox pers. comm.). The only exception was in August 2007 when collections were made for only $2 \mathrm{~d}$. The same colonies were followed throughout the reproductive season both years $(\mathrm{n}=21$ at BTN and $\mathrm{n}=20$ at $\mathrm{GL}$ in 2007, and $\mathrm{n}=20$ for both sites in 2008); 1 colony at BTN died after the 2007 spawning and was excluded from the study in 2008.

Gametes were collected from each adult coral with nets designed to isolate individual colonies for gamete collection while minimizing damage to the colonies or their released gametes and avoiding 
mixing of gametes from neighbor colonies. The cylindrical nets consisted of 3 rings connected to each other with a cylinder of fabric that had a mesh size of $\sim 200 \mu \mathrm{m}$ (Fig. 1e). The heavy bottom ring anchored the net to the substrate; the buoyant surface ring floated on the surface, from which the net extended down through the water column to encircle the entire colony. Lastly the slightly negatively buoyant sinking ring self-adjusted the height of the net to accommodate tidal changes in the height of the water column (Fig. 1e). The nets were placed over the same adult colonies 1 to $2 \mathrm{~h}$ before spawning and were removed once spawning ended (snorkelers were inspecting the colonies) and the egg-sperm bundles inside the net were collected.

\section{Reproductive output}

Most of the collected egg-sperm bundles were broken apart by rinsing them with $0.2 \mu \mathrm{m}$ filtered seawater; after breakage (separation of egg and sperm), the volume of eggs was measured, normalized by colony surface area and used as a proxy for spawning material released per colony (reproductive output). A subset of the freshly collected bundles was used for fertilization trials between colonies from different sites, as well as for microscopic measurements (model SZX7, Olympus) of the number of eggs per bundle and the size of the eggs. The subset was chosen from colonies that had a 'good spawning' night (i.e. they spawned $\sim 2 \mathrm{ml}$ or more). The number of eggs per bundle was used as a proxy of polyp fecundity, since most polyps generally release only 1 egg-sperm bundle in a single evening (Stanton 1993) and each bundle represents the entire reproductive output of the polyp (Heyward 1986, Wallace 1999, J. L. Padillo-Gamiño unpubl. results).

\section{Colony surface area}

The surface area of each coral colony was estimated as the product of an ellipsoid surface and the complexity index. The ellipsoid surface area was calculated by using the greatest aerial diameter of the colony $(X)$ and the diameter perpendicular to it $(Y)$. The complexity index was calculated by using rugosity measurements of the colony along those diameters ( $X$ and $Y$ respectively). The formula used to estimate the colony surface area can be expressed as: $[\pi \times X \times Y \times(X+Y)] /[4 \times(X+Y)]$. Because the coral morphology differed between sites, calix densities were examined in separate branching and plating fragments to examine whether the reproductive surface area differed between morphologies. Fragments from colonies located in the same study sites were collected (4 $\mathrm{cm}$ away from colony tips and edges) where polyps were reproductively active (Wallace 1985, authors' pers. obs.). Coral tissue from these fragments was removed with a dental water flosser (Waterpik Ultra, Waterpik) and the remaining skeletons were bleached and dried. Calyx density was calculated by counting the number of calices present in a $1 \mathrm{~cm}^{2}$ quadrat (5 fragments per morphology, 3 quadrats per fragment).

\section{Fertilization experiments}

In 2008, a subset of egg-sperm bundles from each site was collected for fertilization trials. In June, fertilization trials were performed with 8 and 13 colonies from the BTN and GL sites, respectively; in July, fertilization trials were performed with bundles of 7 and 9 colonies from the BTN and GL sites, respectively. Fertilization trials were performed by using a modified version of that described by Mate et al. (1997). Two egg-sperm bundles from different colonies were placed in a $16 \mathrm{ml}$ glass vial containing $5 \mathrm{ml}$ of $0.2 \mu \mathrm{m}$ filtered seawater. After $5 \mathrm{~h}, 0.5 \mathrm{ml}$ of $25 \%$ Z-fix (Anatech) (diluted with seawater) was added to the vials to preserve the sample and record fertilization success at a later time by using a dissecting microscope; eggs that were at or beyond the 2 cell stage were considered to be fertilized.

\section{Lipid content in the adults before and after spawning}

Lipid content was measured to gain an understanding of the energy reserves available before and after the reproductive season. Total lipids were extracted according to Rodrigues \& Grottoli (2007) from colonies from the BTN $(n=7)$ and GL $(n=9)$ sites before and after spawning during 2007 and 2008 (prespawning: 9 June 2007 and 27 May 2008; postspawning: 30 September 2007 and 21 September 2008). In brief, lipids were extracted from ground samples (skeleton + host tissue + symbiont cells) in a 2:1 chloroform:methanol solution, the organic phase was washed with $0.88 \%$ $\mathrm{KCl}$ and the extract was dried to a constant weight (Harland et al. 1991). Lipids were normalized to total ash-free dry weight of the organic fraction of the coral holobiont (tissue and algal symbionts). 


\section{Statistical analysis}

Means $( \pm \mathrm{SD}$ ) and ranges (minimum-maximum) of temperature and light were calculated for each site during the periods sampled. Temperature and light measurements were compared between years and sites with a Mann-Whitney $U$-test.

A general linear model (GLM) was used to analyze the average proportion of daily spawning colonies at each site (BTN versus GL), year (2007 and 2008), month (June, July and August) and lunar day (during new moon and 1 to $2 \mathrm{~d}$ after). Proportions were arcsine transformed to achieve homogeneity of variances and normality and were verified by Kolmogorov-Smirnov and Levene's tests. Tukey's Honestly Significant Difference multiple comparison tests were conducted as post hoc tests when GLMs detected significant differences.

To analyze whether the spawning probability varied with site, year, month, lunar day, colony and size, a GLM was performed by using a binary logistic regression (yes/no for spawning) and calculated by the maximum-likelihood method. The model was run with size, site, year, month, lunar day and colony as main effects; interaction terms were chosen based on the distribution and availability of the data throughout the reproductive season (e.g. we were not able to test the effects of lunar day on different months because in August of 2008 there was no spawning at all). To determine how well the model fit the data, Pearson and Deviance $\chi^{2}$ goodness-of-fit tests were used.

Total reproductive output (per year) per colony was obtained by summing the material spawned over multiple days and months. Because reproductive output data did not meet the assumptions of homoscedasticity and normality, data were rank-transformed and analyzed with a generalized linear model (GZM) with year, site and colony as main factors.

Differences in the number of eggs per bundle and the coefficient of variation $(\mathrm{CV})$ of that value were examined between sites, years, months and colony using a GLM. The CV describes the SD as a percentage of the mean and is a useful measure of variation, independent of measurement units (Quinn \& Keough 2002). Between 6 and 12 bundles per colony were used to estimate the number of eggs per bundle. Because August spawning was very low (both years), only egg-sperm bundles collected in June and July were used in this analysis.

Simple linear regression analyses for each site and year were used to determine the relationship between colony size and reproductive output, number of eggs per bundle and CV of the number of eggs per bundle.
In addition to quantifying number of eggs per bundle, in 2008 we also estimated the diameter of the eggs in each bundle for 3 colonies per site per month ( $\mathrm{n}=2274$ eggs). The relationship between the number of eggs per bundle and the size of the eggs was explored by using a GLM with site and months as fixed factors and number of eggs as covariate.

The proportion of fertilized eggs was arcsine transformed and analyzed with a 2-way ANOVA with crosses (BTN versus BTN, GL versus GL, BTN versus GL) and month (June and July) as fixed factors.

A GLM was used to examine the effects of year, site and prespawning and postspawning periods on the lipid content of the adults. Lipid data were log transformed to achieve normality and homogeneity of variances.

All statistical analyses were performed with the Minitab statistical package (Minitab 15, Minitab). Values of $p<0.05$ were considered significant.

\section{RESULTS}

\section{Environment}

\section{Comparison of environmental characteristics across spawning years}

The mean temperature was similar in 2007 and 2008 (Mann-Whitney $U$-test: $W=133155, \mathrm{p}=0.929$ ). However, the variability in temperature, as well as in the timing of temperature shifts, was different between years. In 2007, temperature ranged between 21.1 and $28.3^{\circ} \mathrm{C}$, and the minimum temperature occurred in February and the maximum occurred during the 3 mo spawning season for Montipora capitata (June, July and August, Fig. 2a, Table S1 in the Supplement). In contrast, in 2008, temperatures ranged between 20.5 and $29.3^{\circ} \mathrm{C}$, and the rates of decreasing and increasing temperatures were more abrupt; minimum and maximum temperatures occurred during January and July, respectively. In addition, the monthly differences between minimum and maximum temperatures in 2007 were generally $<4^{\circ} \mathrm{C}$, except for April. In 2008, however, there were 5 mo when the range between minimum and maximum temperatures was equal to or $>4^{\circ} \mathrm{C}$ (Fig. 2a, Table S1). The mean total solar radiation was not different between years $(W=133251, \mathrm{p}=0.956)$. During the month of March however, solar radiation was $~ 23 \%$ higher in 2008 than in 2007 (Fig. 2b, Table S1). Precipitation was higher in 2008 than in 2007 by 17\%. In 2007, rainfall was recorded in $185 \mathrm{~d} \mathrm{yr}^{-1}$ for a total 

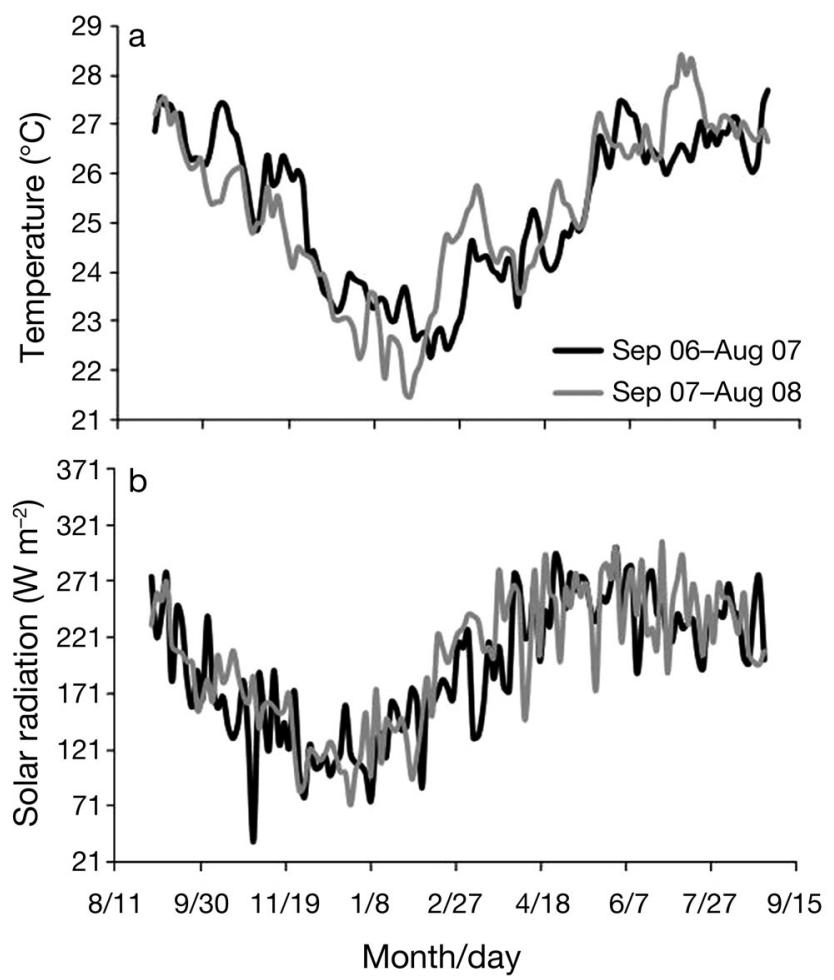

Fig. 2. (a) Temperature and (b) solar radiation for 2007 and 2008 in Moku O Lo'e Island in Kane'ohe Bay, O'ahu, Hawai'i

of $74.16 \mathrm{~cm}$ of rain, and the highest monthly average rainfall occurred in October. In 2008, precipitation was recorded in $177 \mathrm{~d} \mathrm{yr}^{-1}$ for a total of $86.5 \mathrm{~cm}$ of rain, and the highest monthly average rainfall occurred through November and December (Table S1, Fig. S2). During the spawning season (June through August) more rainfall was recorded in 2008. For the most part, trade winds blew from the northeast and east and averaged 17 to $18 \mathrm{~km} \mathrm{~h}^{-1}$; however, the highest maximum wind velocities were observed in January in 2007 and in December in 2008, which coincided with the rainy season for this year (Table S1). In 2007 there was a shift in wind direction; winds blew from the southwest during the period from January to March, which coincided with the month when maximum monthly wind velocities were observed for this year (Fig. S2).

\section{Comparison of environmental characteristics between sites}

Temperature was higher and more variable at the BTN site throughout the year $(W=45411522436$, $\mathrm{p}<$ 0.0001, Fig. 3a) than at the GL site, and up to a $\sim 3^{\circ} \mathrm{C}$ range between minimum and maximum tempera- tures was observed over one $24 \mathrm{~h}$ period. The BTN site was also characterized by higher and broader fluctuations in light intensities in both late summer and late autumn compared with the GL site (September: $W=1773932, p<0.0001$; November: $W=$ 1413 959, $p<0.0001$, Fig. 3b). The GL site experienced an average of $23 \%$ of the light intensity that occurred at the BTN site.

\section{Spawning dynamics}

Spawning, or the release of egg-sperm bundles, in Montipora capitata occurred between 20:45 and 21:15 h during the first quarter of the new moon in June, July and August of 2007 and 2008 (for exact dates see Fig. S3). Spawning events in June occurred slightly earlier (3 to $5 \mathrm{~min}$ ) than spawning events in the following months in both years. The spawning events in both years occurred when tidal amplitudes were at their greatest and the tide was going out. Colonies from the BTN and GL sites spawned at the same time.

There were differences in the daily proportion of colonies that released gametes among years, months and lunar days, and the effect of year depended on site (Fig. 4a,b, Table 1). The daily proportion of spawning colonies was lower at both sites in 2008. In 2007, the proportion of colonies spawning was very similar between sites $(35.7 \%$ at BTN and $34.38 \%$ at GL), whereas in 2008, the proportion of spawning colonies between sites differed (Site $\times$ Year: $F=5.79$, $\mathrm{df}=1, \mathrm{p}=0.033$, Table 1 ) with 15 and $26.1 \%$ of the
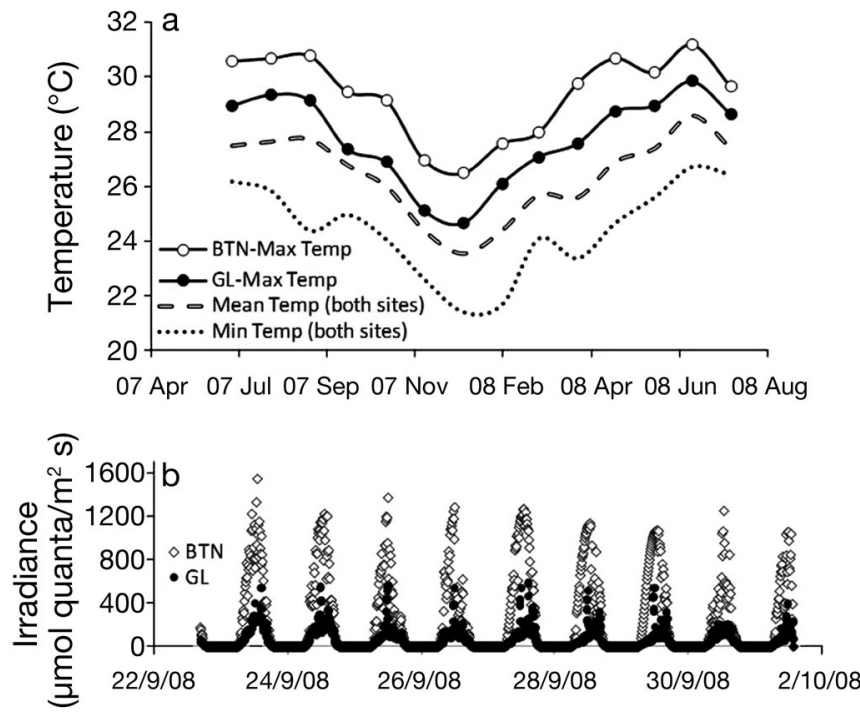

Fig. 3. (a) Temperature and (b) irradiance records from the Bridge to Nowhere (BTN) and Gilligan's Lagoon (GL) sites in Moku O Lo'e Island in Kane'ohe Bay, O'ahu, Hawai'i 
colonies spawning at the BTN and GL sites, respectively. The average proportion of colonies spawning daily declined each month (Month: $F=40.31$, df $=2$; Tukey's test: $\mathrm{p}<0.005$, Table 1) with the most spawning occurring in June (43.4\%), less in July (28.12\%) and the least in August (7.83\%). Although a lunar day effect was detected (Lunar Day: $F=4.65$, df $=2$, $\mathrm{p}=0.032$, Table 1 ), the pairwise comparisons did not reveal any differences in the proportion of colonies releasing gametes among days (Tukey's tests: $\mathrm{p}=$ 0.065 and $\mathrm{p}=0.053$ )

Of the 41 colonies monitored in 2007, 36 colonies spawned at least once and of these 29, 39 and 19.5\% spawned in 1, 2 and 3 mo, respectively. One colony died at the BTN site after the 2007 spawning, so of the 40 colonies observed in 2008, 30 colonies spawned at least once and of these, 42.5, 27.5 and $5 \%$ spawned in 1, 2 and 3 mo. During June and July, most colonies spawned more than once per month, but in August, most colonies spawned only once per month (Fig. S4).
Table 1. Montipora capitata. General linear model (GLM) of the proportion of colonies releasing gametes from the Bridge to Nowhere (BTN) and Gilligan's Lagoon (GL) sites during different years (2007 and 2008), months (June, July and August) and lunar days (new moon and 1 to $2 \mathrm{~d}$ after). Significant $p$-values $(p<0.05)$ in bold

\begin{tabular}{|lrcrc|}
\hline Source & df & MS & \multicolumn{1}{c|}{$F$} & $\mathrm{p}$ \\
\hline Site & 1 & 0.017 & 2.41 & 0.147 \\
Year & 1 & 0.108 & 14.91 & $\mathbf{0 . 0 0 2}$ \\
Month & 2 & 0.292 & 40.31 & $\mathbf{0 . 0 0 0}$ \\
LDay & 2 & 0.034 & 4.65 & $\mathbf{0 . 0 3 2}$ \\
Site $\times$ Year & 1 & 0.042 & 5.79 & $\mathbf{0 . 0 3 3}$ \\
Year $\times$ Month & 2 & 0.008 & 1.04 & 0.383 \\
Site $\times$ LDay & 2 & 0.014 & 1.91 & 0.191 \\
Site $\times$ Month & 2 & 0.005 & 0.64 & 0.545 \\
Month $\times$ LDay & 4 & 0.010 & 1.42 & 0.286 \\
Year $\times$ LDay & 2 & 0.024 & 3.32 & 0.071 \\
Site $\times$ Year $\times$ Month & 2 & 0.007 & 1.02 & 0.391 \\
Error & 12 & 0.007 & & \\
Total & 33 & & & \\
\hline
\end{tabular}
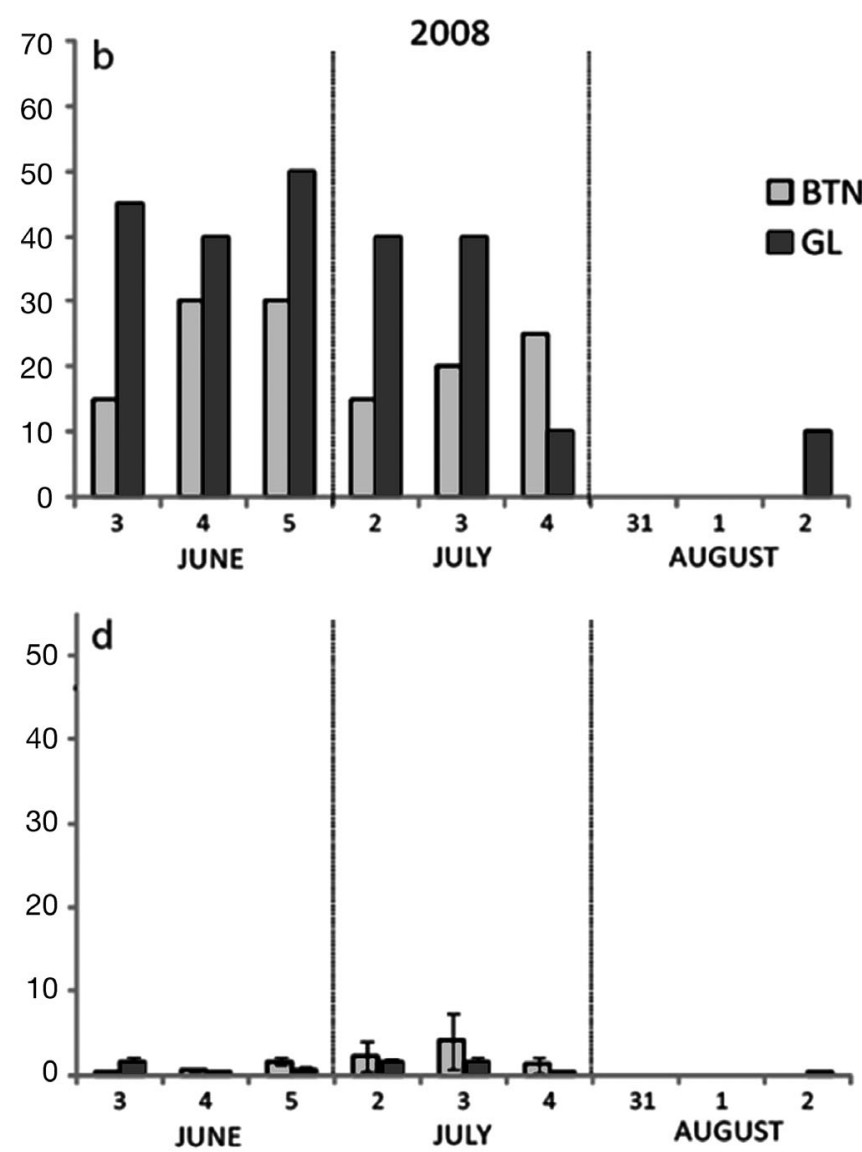

Fig. 4. Montipora capitata. Proportion (\%) of colonies that spawned in (a) 2007 and (b) 2008. Reproductive output (ml eggs $\mathrm{cm}^{-2} \times 10^{-4}$ ) in (c) 2007 and (d) 2008. Light grey bars correspond to the BTN site and dark bars to the GL site. BTN = Bridge to Nowhere: $\mathrm{n}=21$ in 2007 and $\mathrm{n}=20$ in 2008; GL = Gilligan's Lagoon: $\mathrm{n}=20$ in 2007 and 2008. Means $\pm \mathrm{SE}$ 
The probability of spawning was most influenced by year and month (logistic regression: $G=125.46$, $\mathrm{df}=15, \mathrm{p}<0.0001$, Table 2). Both Pearson and Deviance goodness-of-fit tests indicated that the model fits the data well $\left(\chi^{2}=619.8, \mathrm{df}=630, \mathrm{p}=0.606\right.$ and $\chi^{2}=635.1$, df $=630, \mathrm{p}=0.435$; respectively). Coral colonies were more likely to spawn in 2007 than in 2008 ( $p<0.001$, Table 2) and 6 and 3 times more likely to spawn in June and July $(\mathrm{p}<0.001$ and $\mathrm{p}=0.021$, respectively, Table 2) than in August in 2007, and 7 and 8.5 times more likely to spawn in June and July than in August in 2008 ( $p=0.023$ and $\mathrm{p}=0.013$, respectively, Table 2). In 2008 colonies from the GL site were 2.8 times more likely to spawn than colonies from the BTN site. The likelihood of spawning was independent of colony size (Size: $\mathrm{p}=$ 0.107 , Site $\times$ Size: $p=0.106$, Table 2). The estimated colony surface areas ranged between 1385 and

Table 2. Montipora capitata. Results of logistic regression to analyze how spawning probability varies with size, year, month, lunar day and colony. Model comparisons: Site to BTN, Year to 2007, Month to August, Lunar day to 1, Site $\times$ Year BTN 2008, Site $\times$ Month GL August, Year $\times$ Month, $2008 \times$ August. BTN: Bridge to Nowhere; GL: Gilligan's Lagoon. Significant $p$-values $(p<0.05)$ in bold

\begin{tabular}{|lrrrr|}
\hline Predictor & \multicolumn{1}{c}{$\begin{array}{c}\text { Coefficient } \\
\pm \text { SE }\end{array}$} & $Z$ & $\begin{array}{c}\text { p (chi- } \\
\text { square) }\end{array}$ & $\begin{array}{c}\text { Odds } \\
\text { ratio }\end{array}$ \\
\hline Constant & $-2.415 \pm 0.613$ & -3.94 & 0.000 & \\
Size & $0.000 \pm 0.000$ & 1.61 & 0.107 & 1.00 \\
Site & & & & \\
GL & $-0.056 \pm 1.031$ & -0.05 & 0.956 & 0.95 \\
Year & & & & \\
2008 & $-3.053 \pm 0.851$ & -3.59 & $\mathbf{0 . 0 0 0}$ & 0.05 \\
Month & & & & \\
July & $1.140 \pm 0.493$ & 2.31 & $\mathbf{0 . 0 2 1}$ & 3.13 \\
June & $1.799 \pm 0.489$ & 3.68 & $\mathbf{0 . 0 0 0}$ & 6.05 \\
LDay & & & & \\
2 & $0.497 \pm 0.230$ & 2.16 & $\mathbf{0 . 0 3 1}$ & 1.64 \\
3 & $-0.025 \pm 0.250$ & -0.10 & 0.919 & 0.97 \\
Colony (Site) & & & & \\
BTN & $0.007 \pm 0.023$ & 0.30 & 0.761 & 1.01 \\
GL & $0.001 \pm 0.023$ & 0.06 & 0.955 & 1.00 \\
Site $\times$ Year & & & & \\
GL $\times 2008$ & $1.014 \pm 0.404$ & 2.51 & $\mathbf{0 . 0 1 2}$ & 2.76 \\
Site $\times$ Month & & & & \\
GL $\times$ July & $-0.363 \pm 0.671$ & -0.54 & 0.588 & 0.70 \\
GL $\times$ June & $-0.122 \pm 0.662$ & -0.18 & 0.854 & 0.88 \\
Year $\times$ Month & & & & \\
$2008 \times$ July & $2.146 \pm 0.862$ & 2.49 & $\mathbf{0 . 0 1 3}$ & 8.55 \\
$2008 \times$ June & $1.948 \pm 0.854$ & 2.28 & $\mathbf{0 . 0 2 2}$ & 7.02 \\
Site $\times$ Size & & & & \\
GL & $0.000 \pm 0.000$ & 1.62 & 0.106 & 1.00 \\
& & & & \\
\hline
\end{tabular}

$10002 \mathrm{~cm}^{2}$ at the BTN site and between 151 and $9606 \mathrm{~cm}^{2}$ at the GL site. Calix density was $\sim 14.8 \pm$ 1.07 calices $\mathrm{cm}^{-2}$ (mean $\pm \mathrm{SE}$ ) and was similar between colonies with different morphologies (ANOVA: $F=0.69$, df $=29$, p = 0.432).

Colonies had higher reproductive output (volume of eggs per colony surface area) in 2007 than in 2008 (Year: $F=37.87, \mathrm{df}=1, \mathrm{p}<0.001$, Fig. 4c,d, Table 3). A total of 261 and $65 \mathrm{ml}$ of eggs were released in 2007 and 2008, respectively. The largest amounts of spawn were released in June 2007 and in July 2008. It is important to note that 40 of the $65 \mathrm{ml}$ of eggs released in 2008 were spawned by a single colony (Fig. S4). The lowest reproductive output was observed in August at both sites in both years. No differences in reproductive output were observed between sites (Table 3). Reproductive output differed between colonies (Colony: $F=2.04$, df $=1, \mathrm{p}=0.014$, Table 3), which highlights the remarkable variability in reproductive capacity between individuals. Reproductive output was associated with colony size at the GL site (2007, Size: $F=11.6, \mathrm{df}=1, \mathrm{p}=0.004, \mathrm{r}^{2}=$ 0.42 ; 2008, Size: $F=4.86$, df $=1, \mathrm{p}=0.042, \mathrm{r}^{2}=0.23$ ), while at the BTN site, reproductive output was not associated with colony size (2007, Size: $F=0.02$, df $=$ $1, \mathrm{p}=0.888 ; 2008$, Size: $F=0.41, \mathrm{df}=1, \mathrm{p}=0.528$ ) (Fig. S5).

Bundles contained between 8 and 23 eggs each, mean $\pm \mathrm{SE}=$ of $15 \pm 0.3(\mathrm{n}=483)$ eggs per bundle (Fig. 5a). Averaging over both years, there were more eggs per bundle in June than in July (Month: $F=4.11$, df $=1, \mathrm{p}=0.047$, Table 4a). In June of 2007, bundles contained $16.6 \pm 0.53$ eggs $(n=123)$ whereas in July of 2007 bundles contained $13.8 \pm 0.81$ eggs ( $\mathrm{n}=123)$. In 2008, bundles contained similar numbers of eggs in both months: $14.6 \pm 0.69(\mathrm{n}=123)$ and $14 \pm$ $0.44(\mathrm{n}=114)$ in June and July, respectively. Number of eggs per bundle did not differ between sites (Table 4) but was marginally significant with respect to colony variation (Colony: $F=1.59$, df $=33, \mathrm{p}=$

Table 3. Montipora capitata. General linear model of reproductive output (volume [ml] of eggs per colony surface area) by colonies of different sizes at each site (BTN and GL) and year $(2007$ and 2008$)$. Significant $p$-values $(p<0.05)$ in bold

\begin{tabular}{|lrrrc|}
\hline Source & df & \multicolumn{1}{c}{ MS } & \multicolumn{1}{c|}{$F$} & \multicolumn{1}{c|}{ p } \\
\hline Year & 1 & 10948.8 & 37.87 & $\mathbf{0 . 0 0 0}$ \\
Site & 1 & 8.9 & 0.02 & 0.903 \\
Year $\times$ Site & 1 & 208.8 & 0.72 & 0.401 \\
Colony (Site) & 39 & 589.4 & 2.04 & $\mathbf{0 . 0 1 4}$ \\
Error & 39 & 289.1 & & \\
Total & 81 & & & \\
\hline
\end{tabular}



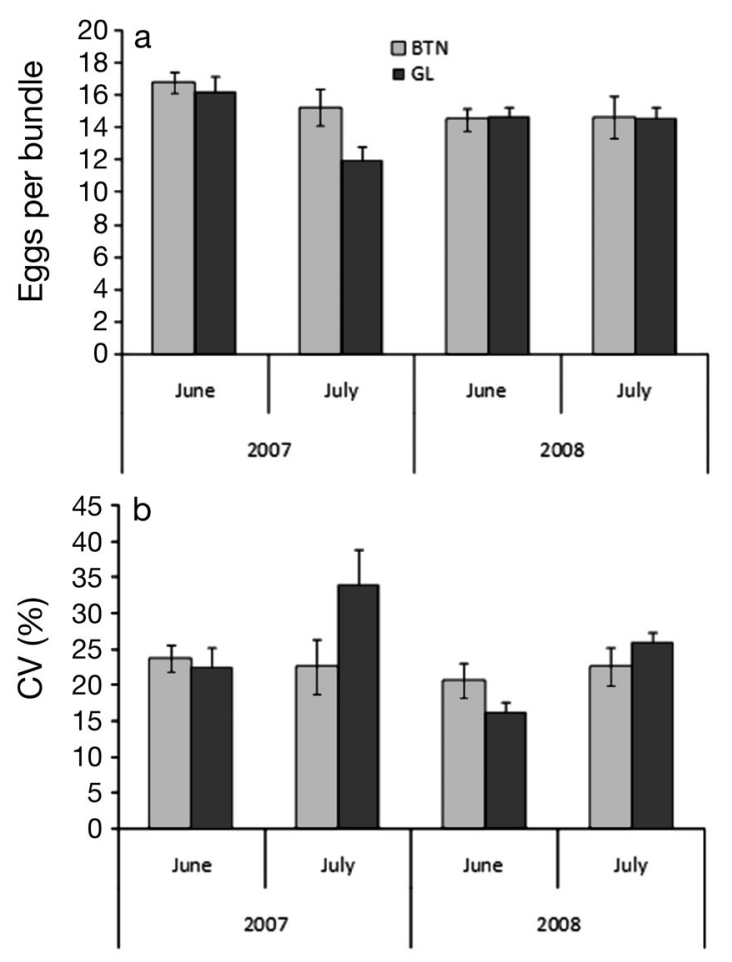

Fig. 5. Montipora capitata. (a) Number of eggs per bundle and (b) coefficients of variation (CV) from colonies at the Bridge to Nowhere (BTN) and Gilligan's Lagoon (GL) sites in June and July of 2007 and 2008. Light grey bars: BTN site; dark bars: GL site. Means \pm SE

0.053, Table 4a). Number of eggs per bundle was associated with colony size only at the BTN site during 2007 (Size: $F=6.34$, df $=1, p=0.019, r^{2}=0.20$ ), but no relationship between the number of eggs per bundle and colony size was found at the BTN site in 2008 or the GL site during both years (BTN 2008, Size: $F=1.12$, df $=1, \mathrm{p}=0.301$; GL 2007, Size: $F=$ 2.46, df =1, p =0.136; GL 2008, Size: $F=0.04, \mathrm{df}=1$, $\mathrm{p}=0.849)$.

The CV, which gives an estimate of the variation in the number of eggs per bundle, differed between years (Year: $F=6.57, \mathrm{df}=1, \mathrm{p}=0.013$, Table $4 \mathrm{~b}$ ). The CV was higher in 2007 than in 2008, but most of this variability was driven by the higher values of $\mathrm{CV}$ at the GL site during the month of July. The CV differed between months at the GL site, but not at the BTN (Site $\times$ Month: $F=10.41$, df $=1, p=0.002$, Table $4 b$ ). At the GL site, the CV increased from $18 \pm 1.3 \%$ (mean $\pm \mathrm{SE}, \mathrm{n}=120$ ) in the month of June to $28.8 \pm$ $2.0 \%(\mathrm{n}=111)$ in July. At the BTN site, the CV was similar, being $22.3 \pm 1.5 \%(\mathrm{n}=126)$ and $22.6 \pm 2.2 \%$ $(\mathrm{n}=126)$ in June and July, respectively. Averaging over both sites, the CV was higher in June than in July. (Month: $F=11.15$, df $=1, p=0.001$, Table $4 b$ ).
Table 4. Montipora capitata. General linear model of the (a) number of eggs per bundle and (b) coefficients of variation for eggs per bundle per colony at each site (BTN and GL), year (2007 and 2008) and month (June and July). Significant $\mathrm{p}$-values $(\mathrm{p}<0.05)$ in bold

\begin{tabular}{|c|c|c|c|c|}
\hline Source & df & MS & $F$ & $\mathrm{p}$ \\
\hline \multicolumn{5}{|c|}{ (a) Number of eggs per bundle } \\
\hline Year & 1 & 19.76 & 2.50 & 0.118 \\
\hline Month & 1 & 32.44 & 4.11 & 0.047 \\
\hline Site & 1 & 15.43 & 1.95 & 0.167 \\
\hline Colony (Site) & 33 & 12.54 & 1.59 & 0.053 \\
\hline Site $\times$ Year & 1 & 22.38 & 2.83 & 0.097 \\
\hline Site $\times$ Month & 1 & 22.40 & 2.84 & 0.097 \\
\hline Year $\times$ Month & 1 & 22.25 & 2.82 & 0.098 \\
\hline Site $\times$ Year $\times$ Month & 1 & 15.91 & 2.01 & 0.160 \\
\hline Error & 70 & 7.90 & & \\
\hline Total & 110 & & & \\
\hline \multicolumn{5}{|c|}{ (b) Coefficient of variation } \\
\hline Year & 1 & 516.56 & 6.57 & 0.013 \\
\hline Month & 1 & 876.6 & 11.15 & 0.001 \\
\hline Site & 1 & 20.56 & 0.26 & 0.611 \\
\hline Colony (Site) & 33 & 68.81 & 0.88 & 0.657 \\
\hline Site $\times$ Year & 1 & 4.37 & 0.06 & 0.814 \\
\hline Site $\times$ Month & 1 & 817.85 & 10.41 & 0.002 \\
\hline Year $\times$ Month & 1 & 6.86 & 0.09 & 0.769 \\
\hline Site $\times$ Year $\times$ Month & 1 & 27.45 & 0.35 & 0.556 \\
\hline Error & 70 & 78.59 & & \\
\hline Total & 110 & & & \\
\hline
\end{tabular}

Colony size did not have an effect on the $\mathrm{CV}$ at any site or year (BTN 2007, Size: $F=0.25$, df $=1, \mathrm{p}=$ 0.622; BTN 2008, Size: $F=0.81, \mathrm{df}=1, \mathrm{p}=0.376$; GL 2007, Size: $F=3.08$, df $=1, p=0.098$; GL 2008, Size: $F=0.96, \mathrm{df}=1, \mathrm{p}=0.333$.

The number of eggs had an effect on the size of the eggs $(F=8.51, \mathrm{p}=0.004$, Table 5$)$; overall egg size tended to decrease with higher number of eggs per bundle. At the BTN site, eggs diameter was slightly smaller in June than in July $(0.383 \pm 0.003 \mu \mathrm{m}$ [mean $\pm \mathrm{SE}$ ] and $0.390 \pm 0.002 \mu \mathrm{m}$, respectively), whereas at the GL site, egg diameter was slightly larger in June than in July $(0.396 \pm 0.003 \mu \mathrm{m}$ and $0.382 \pm 0.004 \mu \mathrm{m}$, respectively) (Site $\times$ Month: $F=$ 7.58, df $=1, \mathrm{p}=0007$, Table 5).

Between 55 and $58 \%$ of eggs per cross were fertilized and there were no differences in the fertilization success among colonies within or between sites, nor among months. The lipid content in the holobiont changed before and after spawning (Prepostspawn: $F=7.94$, df $=1, \mathrm{p}=0.007$, Fig. 6, Table S2). Interestingly, higher lipid contents were found before spawning at the BTN site, but no differences were detected at the GL site (Site $\times$ Prepostspawn: $F=$ 5.85, $\mathrm{p}=$ 0.02, Fig. 6, Table S2). No differences in lipid content were found between sites or years. 
Table 5. Montipora capitata. General linear model of size of eggs with site and months as fixed factors and number of eggs as the covariate. Significant $p$-values $(p<0.05)$ in bold

\begin{tabular}{|lrccc|}
\hline Source & df & MS & $F$ & $p$ \\
\hline NumEggs & 1 & 0.003 & 8.51 & $\mathbf{0 . 0 0 4}$ \\
Site & 1 & 0.001 & 2.43 & 0.121 \\
Month & 1 & 0.001 & 1.49 & 0.224 \\
Site $\times$ Month & 1 & 0.003 & 7.58 & $\mathbf{0 . 0 0 7}$ \\
Error & 158 & 0.000 & & \\
Total & 162 & & & \\
\hline
\end{tabular}

\section{DISCUSSION}

This study explored the spatial and temporal spawning dynamics of a broadcast spawner from the central Pacific Ocean by using a systematic sampling of gametes in the field. Our results indicate that (1) the spawning dynamics in Montipora capitata changed among years, months and lunar days, and (2) the synchrony and proportion of colonies spawning did not change despite colony morphology and environmental differences between sites.

\section{Temporal variability of spawning}

\section{Year}

Spawning dynamics in Montipora capitata changed significantly between years with more coral colonies participating in the split-spawning events, as well as a greater reproductive output in 2007 than in 2008 ( 0.25 the volume of gametes were released in

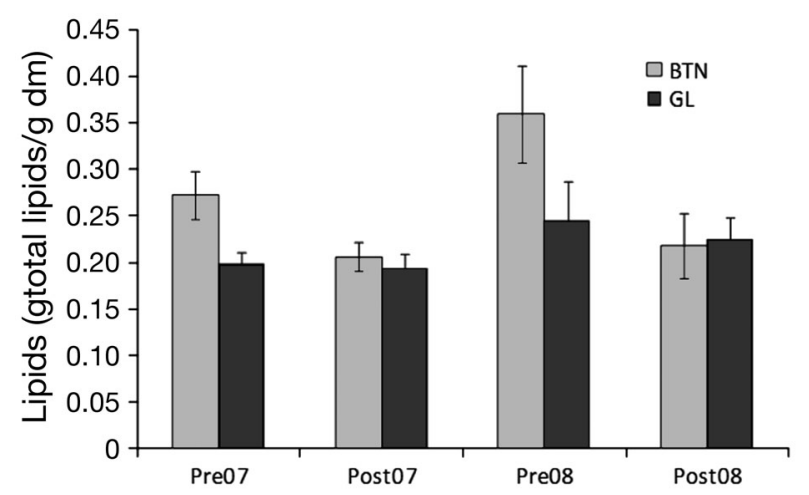

Fig. 6. Montipora capitata. Total lipids (mean \pm SE) in coral colonies before (Pre07, Pre08) and after (Post07, Post08) the reproductive season at the Bridge to Nowhere (BTN) and Gilligan's Lagoon (GL) sites in 2007 and 2008
2008 compared with 2007). There are 2 potential explanations for the differences observed in spawning dynamics between years. First, there were differences in the environmental conditions experienced by corals during gametogenesis in 2007 and 2008 . Spawning (gamete release) is the culmination of important physiological events that occur over an extended period of time in which the gametogenic cells multiply and gametes grow within the gonads. During this period, generally 9 to 10 mo for acroporids like Montipora capitata (Wallace 1985, Shimoike et al. 1993, J. L. Padilla-Gamino, L. Hedouin, D. Smith, W. Truong, R. Waller \& R. D. Gates unpubl. results), coral physiology may be influenced by fluctuations in the environment, which affect reproductive output. By comparison with 2007, 2008 had higher precipitation and wind velocities during winter storm months (November to January), larger temperature fluctuations throughout the year (higher maximum and lower minimum) and slightly lower winds during the warmer season (April to August). In previous years, high temperatures and low winds have been associated with coral bleaching events in Kane'ohe Bay, Hawai'i (Jokiel \& Brown 2004), and in June and July of 2008 temperature values were near or at the bleaching threshold of 29 to $30^{\circ} \mathrm{C}$ for this region.

Bleaching has deleterious and long-lasting effects on the coral reproductive cycle and has been associated with reduced polyp fecundity, egg size, fertilization success and low overall reproductive output for at least $1 \mathrm{yr}$ after the bleaching event (Szmant \& Gassman 1990, Ward et al. 2000, Michalek-Wagner \& Willis 2001, Mendes \& Woodley 2002, McClanahan et al. 2009). Although Montipora capitata colonies did not experience a severe bleaching in 2008, many colonies looked paler than they did in 2007 (personal observation), suggesting that they could be responding to environmental stress. As such it is possible that they used energy for repair and recovery rather than for reproduction in the latter part of 2007 (Sier \& Olive 1994, Michalek-Wagner \& Willis 2001).

Alternatively, the differences we detected in spawning dynamics between years could reflect a shift in the phenology or timing of spawning. In 2008, temperatures rose in February, a month earlier than in 2007, and reached a higher maximum in July. These differences in temperature patterns may have affected the rate of gamete development and caused a change in the timing of spawning. Although Montipora capitata spawning most commonly occurs around the new moon (Hunter 1988), this species has also been observed to spawn rarely during the full 
moon (Heyward 1986, Hunter 1988, F. Cox pers. comm.). It is possible that the major spawning in 2008 occurred around the full moon or several days after the new moon and we failed to detect the spawning because of the timing of our sampling. Such a scenario is supported by our lipid data. Lipids are the main components of coral eggs (Arai et al. 1993), and in the present study similar lipid values were obtained for corals in 2008 and 2007, which suggests that there were equivalent energy reserves available for reproduction in both years. There was also a similar decrease in lipids after reproductive activities in both years, which suggests that, physiologically, the coral colonies exhibited similar changes in energy reserves after reproduction. These findings thus support the view that timing of spawning was atypical and a shift in phenology occurred in 2008, and that we failed to capture it with our sampling.

Very few studies have explored periodic events in coral life cycles and their response to seasonal and interannual variations in climate. Long-term observations ( $\geq 20 \mathrm{yr})$ of spawning events on the Great Barrier Reef have revealed that every 2 to 3 yr coral species that usually spawn in 1 mo, spawn over 2 mo (split spawn), and this is considered to be a mechanism that realigns spawning rhythms (Baird et al. 2009). Field observations (e.g. spawning slick formation, spawning odor; authors' pers. obs.) of Montipora capitata spawning during the summers of 2006 to 2010 suggest that spawning events around the new moon are the norm and that the small magnitude of the spawning event in 2008 was unusual. Although undetected here, it is plausible that $M$. capitata is a species that realigns spawning rhythms through a shift in the timing of spawning (spawning closer to the full moon instead of the new moon). Clearly longer-term data are necessary to accurately assess these hypotheses and characterize spawning variability across larger temporal scales in organisms with life histories like corals that spawn over several decades.

\section{Month and lunar day}

Montipora capitata split-spawned over a 2 to $3 \mathrm{mo}$ period (June to August), which is consistent with previous observations on the reproductive behavior of this species maintained in tanks (Hodgson 1988, Hunter 1988). Spawning events in which coral populations partition the release of gametes over consecutive months are common in many corals species and have been reported in different areas around the world, including the Great Barrier Reef in Australia (Harrison et al. 1984, Willis et al. 1985, Gilmour et al. 2009), Japan (Shimoike et al. 1993, Baird et al. 2009), Singapore (Guest et al. 2005), Thailand (Kongjandtre et al. 2010), Venezuela (Bastidas et al. 2005) and the Persian Gulf (Bauman et al.2011).

The Montipora capitata reproductive season is characterized by high temperatures and low levels of precipitation. Colonies were more likely to spawn in June or July than in August in both years; however, colonies were more likely to spawn in June in 2007 and in July in 2008. These differences could reflect a difference in the timing of the new moon between years; the new moon occurred in the middle of June in 2007 but at the very beginning of June in 2008, and it is plausible that in the latter year, eggs may not have been fully developed and ready to be released (F. Cox pers. comm.). M. capitata is a vertical transmitter and passes endosymbiotic dinoflagellates between generations via the egg. The endosymbionts are translocated into the coral eggs 1 to $12 \mathrm{~d}$ before spawning (Heyward 1986, Hunter 1988, Hirose et al. 2001). As such, the period immediately before spawning is critical for the acquisition of symbionts by the next generation, and an early release of gametes could have detrimental consequences for offspring, since dinoflagellate endosymbionts play an important role in the energy acquisition of coral larvae (Harii et al. 2010).

\section{Spatial variability of spawning}

Site

Spawning dynamics were explored between sites to understand how the reproductive output of colonies was influenced by different environmental characteristics. In 2007, the daily proportion of spawning colonies did not differ between sites, suggesting that colonies exhibited similar reproductive patterns. However, in 2008 the proportion of colonies releasing gametes at the BTN site was lower than at the GL site. BTN had higher fluctuations in temperature and light than the GL site in 2008, and the lower proportion of colonies spawning in 2008 suggests that some colonies experienced higher stress levels that may have compromised reproductive performance at this site. It is important to note, however, that even though there were differences in the proportion of individuals releasing gametes between years at the 2 sites, the amount of material spawned (volume of eggs) was always higher at the BTN site. At this site, 
colonies exhibited predominantly branching morphologies and had greater reproductive surface than the plating colonies found at the GL site. Reproductive output normalized by surface, however, was not different between sites.

Previous manipulative experiments in broadcast spawners have shown that temperature, lunar phase and day length can influence the timing of spawning (Hunter 1988, Brady et al. 2009). Lowering the temperature during the spawning season can prevent the release of gametes in Montipora capitata (previously known as M. verrucosa) in Hawaii (Hunter 1988). Furthermore, alterations in the local solar light cycle shift the timing of the spawning in M. capitata (Hunter 1988) and Montastraea franski (Brady et al. 2009). In our study, the release of gametes of M. capitata occurred at the same time of day despite differences in the temperature regimes, light levels and morphology between the 2 sites. This suggests that both populations were responding similarly to spawning cues (e.g. hormones, light-dark rhythms) (Atkinson \& Atkinson 1992, Gorbunov \& Falkowski 2002, Tarrant et al. 2004, Levy et al. 2007) and is consistent with the observations of Bastidas et al. (2005), who found no differences in coral spawning synchrony in 7 coral species in inshore and offshore reefs with different environmental characteristics in Venezuela. In contrast, inshore corals on the Great Barrier Reef spawned 1 mo earlier than did corals from offshore reefs, a scenario possibly driven by rapid seasonal warming of the shallower reefs (Willis et al. 1985). It is important to note, however, that these studies were all performed at very different spatial scales to ours and so are not directly comparable. Clearly, there is a need for further research aimed at understanding how corals regulate their remarkable synchronicity and how spawning cues are perceived and transduced by the organism, particularly when colonies experience very different environmental conditions.

\section{Colony}

The Montipora capitata colonies in this study were variable in size and morphologies (Fig. S1) and also shared characteristics of different 'morphospecies' (Forsman et al. 2010). However, all colonies spawned simultaneously and gametes from colonies within and between sites successfully fertilized one another, which supports the hypothesis that all colonies were the same species. The latter is also supported by phylogenetic analyses of $M$. capitata from these sites, which showed that colonies with different morpholo- gies share common alleles (J. L. Padilla-Gamino, X. Pochon, C. Bird, G. T. Concepcion \& R. D. Gates unpubl. results).

Tracking the reproductive outputs in individual colonies through multiple days and 2 reproductive seasons revealed large variability in reproductive output and frequency of spawning (months, nights per month) among colonies. For example, some colonies released gametes once in the reproductive season, whereas others released gametes in multiple months and more than once each month (Fig. S4). Releasing gametes over several periods is considered beneficial because it minimizes risk associated with catastrophic events (Richmond \& Hunter 1990). The variability detected here indicates that members of coral populations have different physiological responses to factors controlling gamete development and vary in their reproductive investments (Harrison \& Wallace 1990).

Making observations and collecting gametes in the field also allowed us to examine spawning dynamics in unmanipulated colonies representing a broad size range in their natural habitat. Our results show that colony size did not influence the likelihood of spawning; gamete release was very variable between colonies of all sizes. Interestingly, reproductive output (volume of eggs per colony surface area) was influenced by colony size at the GL site (plating morphology) but not at the BTN site (branching morphology). At the BTN site, some of the small colonies released similar or larger amounts of spawn than colonies that were 4 to 7 times larger. In fact, the largest amount of material spawned material by a colony was released by one of the smallest colonies at the BTN site (Fig. S3). This larger variation in reproductive capacity may be due, in part, to the larger morphological complexity of the branching colonies and the variation of light availability in different parts of the colony (Kaniewska et al. 2008).

It is important to note that sexual maturity and age in corals does not always link to colony size, and reproductive output can also be affected by colony senescence (Rinkevich \& Loya 1986). While our study included colonies from several size classes and many were larger than those examined in previous laboratory studies, we still did not encompass the very largest size class in the population ( 2 to $3 \mathrm{~m}$ wide). Future research examining the largest colonies of the population, as well as the smaller ones, is necessary to explore the reproductive capacity (and possible senescence) of Montipora capitata and how size and sexual reproduction vary between colonies owing to age or physiological condition. 
Polyp

Montipora capitata is hermaphroditic and polyps release gametes simultaneously as packages (eggsperm bundles) (Heyward 1986). In this study, reproductive output per polyp was explored by using the number of eggs per bundle as a proxy for polyp fecundity. Despite large differences in colony size and morphology (Figs. S1 \& S3), as well as environmental differences at the study sites, the number of eggs per bundle was very consistent (except for BTN in 2007, where the number of eggs per bundle was slightly associated with colony size, $\mathrm{r}^{2}=0.2$ ), which suggests that fecund polyps allocated similar energy reserves to reproduction. Similar results were observed in Montastraea faveolata (Villinski 2003) where no differences in the egg production per polyp were found between colonies from different depths (3 versus $18 \mathrm{~m}$ ). Likewise, colony size had no effect on egg or testes number per polyp or testes volume per polyp for 6 reef-building corals studied by Hall \& Hughes (1996).

However, temporal differences in the number of eggs per bundle were observed in the present study. In 2007, bundles with more eggs were released early in the reproductive season. However, in 2008 (the year with low reproductive output) no differences were found in the number of eggs released between the 2 mo. In most coral species, gametes typically develop with high synchrony among polyps (Harrison \& Wallace 1990). However, in many species, marginal polyps in the periphery of colonies are 'nonreproductive zones' and do not produce gametes, possibly owing to the allocation of energy resources to colony defense and expansion rather than reproduction (Kojis \& Quinn 1982, Szmant-Froelich 1985, Hall \& Hughes 1996, Kapela \& Lasker 1999, Smith \& Hughes 1999). It is also important to note that corals are modular organisms composed of many interdependent polyps, each with its own birth, growth and death rates (Hughes 1989, Baird et al. 2009), each of which is exposed to different micro-environmental conditions (Kaniewska et al. 2008).

In Acropora spp., differences in the timing of spawning and egg maturation have been observed in polyps depending on their location within the colony (Shimoike et al. 1993). Shimoike et al. (1993) found that polyps located in the shaded part of the colony spawned a day later and their eggs had lower volume, suggesting that different light conditions affected the allocation of energy for reproduction within the same colony. It is therefore possible that branching colonies of Montipora capitata at the BTN site may have larger intracolony variability in the allocation of energy for reproduction than plate morphologies at the GL site owing to their more complex morphology. Interestingly, the $\mathrm{CV}$ differed between months in both years at the GL site but not at the BTN site. This is contrary to what we expected as the GL site colonies have a simpler morphology (plate) and experience lower environmental fluctuations (light and temperature) than they do at the BTN site; originally we had expected larger variation in the propagules of colonies with more complex morphologies (e.g. branching).

In Montipora capitata, there was a relationship between the number of eggs per bundle and the size of the eggs (Table 5). Generally, bundles with smaller eggs had more eggs per bundle and those with larger eggs had fewer eggs per bundle. It is still unclear what drives this variability, but it is possible that the relationship between size and number of eggs depends on the polyp's size, age or position within the colony, which could combine to affect their capacity to package bundles before spawning.

Gamete size variation has not been well studied in colonial marine organisms (Marshall \& Keough 2008). Egg size can influence the chances of being fertilized as larger eggs having a higher chance of sperm encounter than do smaller eggs (Levitan 1996, Marshall et al. 2000, 2002). In our study, the size of the eggs showed different trends at the BTN and GL sites. At the BTN site, larger eggs were found early in the season (June) and smaller eggs late in the season (July); the opposite was true for the GL site. It is unclear, however, if these patterns were due to differences in gamete development between sites. Future studies should also measure sperm content per bundle and how it relates to both the egg size and the number of eggs in the bundle; it is possible that a shift in size or number of eggs may be accompanied by a shift in sperm production. Hall \& Hughes (1996) found that the ratio of total egg volume to testes volume per polyp increased with colony size in the 6 reef-building corals studied.

Recent studies of gamete plasticity in colonial invertebrates in the field have revealed important insights of the parental effects on gamete size. Monro et al. (2010) studied the relationship between offspring size and performance in the colonial bryozoan Bugula neritina. Their work suggests that plasticity in offspring size can optimize fitness when the environment is unpredictable (bet hedging). Crean \& Marshall's (2008) research on the broadcast-spawning ascidian Styela plicata revealed that both egg and sperm showed phenotypic plasticity in response 
to changes in adult density (sperm environment). When adult density was higher, eggs with larger ovicells (portion of the egg available for embryonic development) were produced, and sperm were larger and more motile and also remained viable for longer than did the sperm collected from adults with low density.

Thus, all gametes are not created equal, and when the environment of the offspring is unpredictable this variation may have a beneficial value (Crean \& Marshall 2009). It is not clear how much corals can control the phenotypic plasticity of their gametes, but this may have important implications for survival of coral offspring. Further research is necessary in this novel and exciting field.

Spawning synchrony is of critical importance for broadcast-spawning marine invertebrates. However, spawning is a complex phenomenon that depends on the physiological response of organisms to several environmental cues that vary both in time and space over several scales. The present work is one of the most comprehensive studies of spawning dynamics in the field and represents the first ecological spawning baseline for a reef-building coral in the central Pacific Ocean. Our data demonstrate that in situ spawning dynamics of the scleractinian coral Montipora capitata vary significantly between years, months and lunar days and between sites, colonies and polyps. The environmental conditions in a 'good spawning year' for $M$. capitata were characterized by warmer temperatures in the winter, cooler temperatures during the summer $\left(<28^{\circ} \mathrm{C}\right)$ and low precipitation during the spawning season (June to August). However, longer time series would help us determine whether the differences in spawning between years were simply part of the natural variability or whether there may have been antecedent environmental or physiological differences causing the change. Further research is necessary to understand the causes of variability at all these scales and how spawning cues may interact and affect the reproductive physiology at the population, organism and polyp (module) level. Understanding these relationships will help us to better predict the effects of climate change on the phenology and reproductive success of corals, which are critical for the resilience and persistence of coral reefs and the survival of many species in the tropical seas.

Acknowledgements. Thanks to all 170 wonderful volunteers who helped to collect the samples during the spawning events, especially S. Wagenhouser, C. Portocarrero, M. Sales, A. Cozo, R. Gabriel, M. Hagedorn, G. Carter, F. Kandel, S. Leon, D. Barshis, D. Reineman, P. Quiroga, the 2007
Edwin W. Pauley Summer Program students at Hawai'i Institute of Marine Biology (HIMB) and the Marine Option Program (MOP) students from the University of Hawai'i (UH). Special thanks to Dr. Donahue and Dr. Zvuloni for their assistance with the data analysis, to Dr. Rodrigues for lab assistance with lipid analysis, and to J. Johnson for the spawning picture. Thanks to the Point Lab at HIMB (K. Rodgers and F. Cox) and the Hawaii corrosion lab at UH (L. Hihara, G. Hawthorn and M. Nullet) for their helpful assistance in obtaining the records from the meteorological stations. Thanks to Dr. F. Cox, Dr. Kinzie, Dr. Karl, Dr. Waller and the anonymous reviewers for their helpful comments. J.L.P.G. was supported by a CONACYT Graduate Research Fellowship, the World Bank CRTR program and C-MORE. The research was funded by the Pauley Foundation, the World Bank CRTR program and National Science Foundation (OCE-0752604 to R.D.G.). This is 2007 Edwin W. Pauley Summer Program contribution 6, HIMB contribution number 1478 and SOEST contribution number 8528.

\section{LITERATURE CITED}

Arai T, Kato M, Heyward A, Ikeda Y, Iizuka T, Maruyama T (1993) Lipid-composition of positively buoyant eggs of reef building corals. Coral Reefs 12:71-75

Atkinson S, Atkinson MJ (1992) Detection of estradiol-17 during a mass coral spawn. Coral Reefs 11:33-35

Babcock RC, Bull GD, Harrison PL, Heyward AJ, Oliver JK, Wallace CC, Willis BL (1986) Synchronous spawnings of 105 scleractinian coral species on the Great Barrier Reef. Mar Biol 90:379-394

> Babcock R, Mundy C, Keesing J, Oliver J (1992) Predictable and unpredictable spawning events: in-situ behavioural data from free-spawning coral reef invertebrates. Invertebr Reprod Dev 22:213-228

Baird AH, Guest JR, Willis BL (2009) Systematic and biogeographical patterns in the reproductive biology of scleractinian corals. Annu Rev Ecol Evol Syst 40:551-571

- Bastidas C, Croquer A, Zubillaga AL, Ramos R, Kortnik V, Weinberger C, Marquez LM (2005) Coral mass- and split-spawning at a coastal and an offshore Venezuelan reefs, southern Caribbean. Hydrobiologia 541:101-106

Bauman A, Baird A, Cavalcante G (2011) Coral reproduction in the world's warmest reefs: southern Persian Gulf (Dubai, United Arab Emirates). Coral Reefs 30:405-413

> Brady AK, Hilton JD, Vize PD (2009) Coral spawn timing is a direct response to solar light cycles and is not an entrained circadian response. Coral Reefs 28:677-680

> Crean AJ, Marshall DJ (2008) Gamete plasticity in a broadcast spawning marine invertebrate. Proc Natl Acad Sci USA 105:13508-13513

> Crean AJ, Marshall DJ (2009) Coping with environmental uncertainty: dynamic bet hedging as a maternal effect. Philos Trans R Soc Lond B Biol Sci 364:1087-1096

> Fan TY, Dai CF (1999) Reproductive plasticity in the reef coral Echinopora lamellosa. Mar Ecol Prog Ser 190: 297-301

Forsman ZH, Concepcion GT, Haverkort RD, Shaw RW, Maragos JE, Toonen RJ (2010) Ecomorph or endangered coral? DNA and microstructure reveal Hawaiian species complexes: Montipora dilatata/flabellata/turgescens \& M. patula/verrilli. PLoS ONE 5:e15021

Gilmour JP, Smith LD, Brinkman RM (2009) Biannual spawning, rapid larval development and evidence of 
self-seeding for scleractinian corals at an isolated system of reefs. Mar Biol 156:1297-1309

Gorbunov MY, Falkowski PG (2002) Photoreceptors in the cnidarian hosts allow symbiotic corals to sense blue moonlight. Limnol Oceanogr 47:309-315

Guest JR, Baird AH, Goh BPL, Chou LM (2005) Reproductive seasonality in an equatorial assemblage of scleractinian corals. Coral Reefs 24:112-116

Hall VR, Hughes TP (1996) Reproductive strategies of modular organisms: comparative studies of reef-building corals. Ecology 77:950-963

Harii S, Yamamoto M, Hoegh-Guldberg O (2010) The relative contribution of dinoflagellate photosynthesis and stored lipids to the survivorship of symbiotic larvae of the reef-building corals. Mar Biol 157:1215-1224

Harland AD, Fixter LM, Spencer Davies P, Anderson RA (1991) Distribution of lipids between the zooxanthellae and animal compartment in the symbiotic sea anemone Anemonia viridis: wax esters, triglycerides and fatty acids. Mar Biol 110:13-19

Harrison PL (2011) Sexual reproduction of scleractinian corals. In: Dubinsky Z, Stambler N (eds) Coral reefs: an ecosystem in transition. Springer, London

Harrison PL, Wallace CC (1990) Reproduction, dispersal and recruitment of scleractinian corals. In: Dubinsky Z (ed) Ecosystems of the world, coral reefs. Elsevier Science, Amsterdam

> Harrison PL, Babcock RC, Bull GD, Oliver JK, Wallace CC, Willis BL (1984) Mass spawning in tropical reef corals. Science 223:1186-1189

Heyward AJ (1986) Sexual reproduction in five species of the coral Montipora. In: Jokiel PH, Richmond RH, Rogers $\mathrm{R}$ (eds) Coral reef population biology. University of Hawaii, Honolulu, HI

> Himmelman JH, Dumont CP, Gaymer CF, Vallieres C, Drolet D (2008) Spawning synchrony and aggregative behaviour of cold-water echinoderms during multispecies mass spawnings. Mar Ecol Prog Ser 361:161-168

Hirose M, Kinzie RA, Hidaka M (2001) Timing and process of entry of zooxanthellae into oocytes of hermatypic corals. Coral Reefs 20:273-280

Hodgson G (1985) Abundance and distribution of planktonic coral larvae in Kaneohe bay, Oahu, Hawaii. Mar Ecol Prog Ser 26:61-71

Hodgson G (1988) Potential gamete wastage in synchronously spawning corals due to hybrid inviability. In: Proc 6th Int Coral Reef Symp, Townsville 2:707-714

Hughes RN (1989) A functional biology of clonal animals. Chapman, New York, NY

> Hughes L (2000) Biological consequences of global warming: Is the signal already apparent? Trends Ecol Evol 15: 56-61

Hunter CL (1988) Environmental cues controlling spawning in two Hawaiian corals, Montipora verrucosa and M. dilatata. In: Proc 6th Int Coral Reef Symp, Townsville 2:727-732

> Jokiel PH, Brown EK (2004) Global warming, regional trends and inshore environmental conditions influence coral bleaching in Hawaii. Glob Change Biol 10: 1627-1641

> Jokiel PL, Brown EK, Friedlander A, Rodgers SK, Smith WR (2004) Hawai'i coral reef assessment and monitoring program: spatial patterns and temporal dynamics in reef coral communities. Pac Sci 58:159-174

Kaniewska P, Anthony KRN, Hoegh-Guldberg O (2008)
Variation in colony geometry modulates internal light levels in branching corals, Acropora humilis and Stylophora pistillata. Mar Biol 155:649-660

Kapela W, Lasker HR (1999) Size-dependent reproduction in the Caribbean gorgonian Pseudoplexaura porosa. Mar Biol 135:107-114

Kojis BL, Quinn NJ (1982) Reproductive ecology of two faviid corals (Coelenterata: Scleractinia). Mar Ecol Prog Ser 8:251-255

Kongjandtre N, Ridgway T, Ward S, Hoegh-Guldberg O (2010) Broadcast spawning patterns of Favia species on the inshore reefs of Thailand. Coral Reefs 29:227-234

Levitan DR (1996) Predicting optimal and unique egg sizes in free-spawning marine invertebrates. Am Nat 148: $174-188$

Levitan DR, Fogarty ND, Jara J, Lotterhos KE, Knowlton N (2011) Genetic, spatial, and temporal components of precise spawning synchrony in reef building corals of the Montastraea annularis species complex. Evolution 65: 1254-1270

Levy O, Appelbaum L, Leggat W, Gothlif Y, Hayward DC, Miller DJ, Hoegh-Guldberg H (2007) Light-responsive cryptochromes from a simple multicellular animal, the coral Acropora millepora. Science 318:467-470

Maragos JE (1972) A study of the ecology of Hawaiian reef corals. PhD dissertation, University of Hawaii, Honolulu

Marshall DJ, Keough MJ (2008) The evolutionary ecology of offspring size in marine invertebrates. In: Sims DW (ed) Advances in marine biology, Vol 53. Academic Press, London, p 1-60

Marshall DJ, Styan CA, Keough MJ (2000) Intraspecific covariation between egg and body size affects fertilisation kinetics of free-spawning marine invertebrates. Mar Ecol Prog Ser 195:305-309

> Marshall DJ, Styan CA, Keough MJ (2002) Sperm environment affects offspring quality in broadcast spawning marine invertebrates. Ecol Lett 5:173-176

Mate JL, Wilson J, Field S, Neves EG (1997) Fertilization dynamics and larval development of the scleractinian coral Montipora verrucosa in Hawai'i. In: Cox EF, Krupp DA, Jokiel PH (eds) Reproduction in reef corals. Results of the 1997 Edwin W. Pauley Summer Program in Marine Biology. Hawaii Institute of Marine Biology, Kane'ohe, HI, p 121-128

McClanahan TR, Weil E, Cortes J, Baird A (2009) Consequences of coral bleaching for sessile reef organisms. In: van Oppen MJH, Lough JM (eds) Ecological studies: coral bleaching: patterns, processes, causes and consequences. Springer, Berlin

Mendes JM, Woodley JD (2002) Timing of reproduction in Montastraea annularis: relationship to environmental variables. Mar Ecol Prog Ser 227:241-251

Mercier A, Hamel JF (2010) Synchronized breeding events in sympatric marine invertebrates: role of behavior and fine temporal windows in maintaining reproductive isolation. Behav Ecol Sociobiol 64:1749-1765

Michalek-Wagner K, Willis BL (2001) Impacts of bleaching on the soft coral Lobophytum compactum. I. Fecundity, fertilization and offspring viability. Coral Reefs 19: 231-239

> Minchin D (1992) Multiple species, mass spawning events in an Irish sea lough: the effect of temperatures on spawning and recruitment of invertebrates. Invertebr Reprod Dev 22:229-238

Monro K, Sinclair-Taylor T, Marshall DJ (2010) Selection on 
offspring size among environments: the roles of environmental quality and variability. Funct Ecol 24:676-684

Padilla-Gamino JL, Weatherby $\mathrm{T}$, Waller RG, Gates RD (2011) Formation and structural organization of the eggsperm bundle of the scleractinian coral Montipora capitata. Coral Reefs 30:371-380

Quinn G, Keough M (2002) Experimental design and data analysis for biologists. Cambridge University Press, Cambridge

Richmond RH, Hunter CL (1990) Reproduction and recruitment of corals: comparisons among the Caribbean, the Tropical Pacific, and the Red Sea. Mar Ecol Prog Ser 60: 185-203

Rinkevich B, Loya Y (1986) Senescence and dying signals in a reef building coral. Experientia 42:320-322

Rodrigues LJ, Grottoli AG (2007) Energy reserves and metabolism as indicators of coral recovery from bleaching. Limnol Oceanogr 52:1874-1882

Shimoike K, Hayashibara T, Kimura T, Omori M (1993) Observations of split spawning in Acropora spp. at Akajima island, Okinawa. In: Proc 7 th Int Coral Reef Symp, Guam 1:484-488

Sier CJS, Olive PJW (1994) Reproduction and reproductive variability in the coral Pocillopora verrucosa from the Republic of Maldives. Mar Biol 118:713-722

Smith L, Hughes TP (1999) An experimental assessment of survival, re-attachment and fecundity of coral fragments. J Exp Mar Biol Ecol 235:147-164

Stanton FG (1993) Spatio-temporal patterns of spawning in the coral Montipora verrucosa in Hawaii. In: Proc 7th Int Coral Reef Symp, Guam 1:489-493

Szmant A, Gassman NJ (1990) The effects of prolonged 'bleaching' on the tissue biomass and reproduction of the

Editorial responsibility: Charles Birkeland,

Honolulu, Hawaii, USA reef coral Montastrea annularis. Coral Reefs 8:217-224

Szmant-Froelich A (1985) The effect of colony size on the reproductive ability of the Caribbean coral Montastrea annularis (Ellis \& Solander). Proc 5th Int Coral Reef Congr, Tahiti 4:295-300

Tarrant AM, Atkinson MJ, Atkinson S (2004) Effects of steroidal estrogens on coral growth and reproduction. Mar Ecol Prog Ser 269:121-129

van Veghel MLJ (1993) Multiple species spawning on Curacao Reefs. Bull Mar Sci 52:1017-1021

van Woesik R (2010) Calm before the spawn: global coral spawning patterns are explained by regional wind fields. Proc R Soc Lond B Biol Sci 277:715-722

van Woesik R, Lacharmoise F, Koksal S (2006) Annual cycles of solar insolation predict spawning times of Caribbean corals. Ecol Lett 9:390-398

Villinski JT (2003) Depth-independent reproductive characteristics for the Caribbean reef-building coral Montastraea faveolata. Mar Biol 142:1043-1053

> Wallace CC (1985) Reproduction, recruitment and fragmentation in nine sympatric species of the coral genus Acropora. Mar Biol 88:217-233

Wallace C (1999) Staghorn corals of the world: a revision of the coral genus Acropora. Commonwealth Scientific and Industrial Research Organisation (CSIRO), Collingwood

Ward S, Harrison PL, Hoegh-Gulberg O (2000) Coral bleaching reduces reproduction of scleractinian corals and increases susceptibility to future stress. Proc 9th Int Coral Reef Symp, Bali 2:1123-1128

Willis BL, Babcock RC, Harrison PL, Oliver JK (1985) Patterns in the mass spawning of corals on the Great Barrier Reef from 1981 to 1984. Proc 5th Int Coral Reef Congr, Tahiti 4:343-348

Submitted: September 23, 2011; Accepted: November 26, 2011 Proofs received from author(s): February 17, 2012 